\title{
SUPPORT SISTEM KELUARGA PADA PASIEN GAGAL GINJAL KRONIS YANG MENJALANI HEMODIALISA DI RSUD ULIN BANJARMASIN 2020
}

\author{
Iriani, Helda ${ }^{1}$, Hamzah $^{2}$, Budiyarti, Yuliani ${ }^{3}$ \\ ${ }^{1}$ Mahasiswa Pascasarjana Ilmu Keperawatan Universitas Muhammadiyah Banjarmasin, 70114, \\ Indonesia \\ ${ }^{2}$ Staff Dosen Fakultas Kedokteran Universitas Airlangga Surabaya, 60132,Indonesia \\ ${ }^{3}$ Staff Dosen Pascasarjana Ilmu Keperawatan Universitas Muhammadyah Banjarmasi, 70114, \\ Indonesia
}

Email: heldairiani123@gmail.com

\begin{abstract}
Abstrak
Latar Belakang: Proses hemodialisa yang lama pada pasien GGK akan menimbulkan stress fisik dan juga psikologis, gangguan proses berfikir dan konsentrasi serta gangguan dalam hubungan sosial yang berdampak pada segi fisik, mental, dan sosial. Terapi hemodialisa juga cukup berdampak pada kualitas hidup pasien gagal ginjal kronik, sehingga diperlukanya dukungan keluarga. Menarik untuk mengetahui pengalaman keluarga memberikan dukungan pada pasien gagal ginjal kronis untuk menjalani hemodialisa.

Metode: Penelitian ini menggunakan pendekatan kualitatif deskriptif dengan metode wawancara mendalam (indept interview). Partisipan yang digunakan sebanyak 6 orang yaitu keluarga pasien gagal ginjal kronis yang menjalani hemodialisa di RSUD Ulin Banjarmasin.

Hasil: Penelitian ini menemukan 9 tema yaitu Sumber Informasi tentang Hemodialisa/cuci darah, Cara Keluarga Memberikan Dukungan, Dukungan yang diberikan, Pentingnya Dukungan Keluarga, Sumber Informasi Dukungan yang diberikan, Harapan Keluarga setelah Memberikan Dukungan, Hambatan Saat Memberikan Dukungan, Cara Keluarga mengatasi Hambatan saat Memberikan Dukungan, Keyakinan akan Dukungan yang Diberikan bisa Meningkatkan Kesehatan.

Kesimpulan: Tenaga kesehatan diharapkan mampu menguasai dan memahami edukasi dan cara pemberian motivasi yang baik pada keluarga pasien gagal ginjal Kronik yang menjalani hemodialisa selama dirawat dirumah sakit.
\end{abstract}

Kata Kunci: Gagal Ginjal Kronis, Hemodialisa, Support Sistem Keluarga 


\section{PENDAHULUAN}

Dewasa ini penyakit gagal ginjal kronik (GGK) menjadi salah satu masalah serius bagi dunia kesehatan baik skala internasional, nasional maupun lokal di mana angka kejadian penyakit ini semakin meningkat setiap tahunnya. Global Burden of Disease Study (2015) menguraikan penyakit GGK menduduki peringkat ke-12 penyebab kematian di dunia, dengan angka mortalitas sebesar 31,7\% selama 10 tahun terakhir. Prevalensi GGK didunia juga dijelaskan oleh International Society of Nefhrology (ISN,2018) bahwa saat ini mencapai angka 22,2\% pada tahun 2017 dan meningkat menjadi 26,8\% pada tahun 2018 di mana $15,8 \%$ diantaranya memerlukan tindakan hemodialisa dan transplantasi ginjal.

Laporan Indonesia Renal Registary melaporkan data pasien GGK yang menjalani hemodialisa pada tahun 2017 yaitu sebesar $32,2 \%$, meningkat menjadi $42,2 \%$ pada tahun 2018 (IRR, 2018). Peningkatan kejadian GGK juga terjadi di Kalimantan selatan, di mana Dinas Kesehatan Provinsi Kalimantan Selatan mencatat kejadian GGK pada tahun 2017 berjumlah $21,7 \%$ dan meningkat sebesar $2,7 \%$ pada tahun 2018 serta berada pada urutan ke-9 dari 10 penyakit terbanyak yang diderita.

Penanganan penyakit GGK (Gagal Ginjal Kronik) yang cukup sulit seperti tindakan transplantasi ginjal dengan donor yang harus sesuai serta memerlukan biaya cukup mahal ataupun tatalaksana hemodialisa yang harus terus menerus serta berkelanjutan, membuat penyakit GGK (Gagal Ginjal Kronik) ini harus mendapat perhatian yang besar.

Data yang didapat dari ruangan rawat inap Tulip 3BC RSUD Ulin Banjarmasin jumlah penderita GGK yang menjalani hemodialisa secara keseluruhan pada tahun 2017-2018 mengalami peningkatan tiap tahunnya dengan peningkatan angka kematian sebesar 24\% (74 dari 304 orang) yang sebelumnya hanya sebesar 14\% (40 dari 277 orang). Perhitungan dari bulan maret sampai dengan juli tahun 2019 jumlah pasien yang menderita gagal ginjal kronik yang menjalani hemodialisa berjumlah 196 orang dan sebesar 18\% telah meninggal dunia (35 dari 196 orang).

Winata, et al (2017) menguraikan hemodialisa merupakan salah satu terapi pengganti kerja ginjal yang rusak tetapi terapi ini dapat menyebabkan gangguan pada aspek biologis maupun aspek psikologis yang dapat mempengaruhi kualitas hidup penderita, sehingga sangat diperlukan dukungan keluarga sebagai sistem pendukung bagi pasien untuk menghadapi masalah yang mungkin akan terjadi pada saat menjalani proses hemodialisa.

Setiadi (2008) menguraikan sebuah teori tentang perkembangan keluarga yang dikemukakan oleh Friedman yaitu apabila salah satu anggota keluarga mengalami masalah pada kesehatanya maka anggota keluarga lainya yang berperan untuk memberikan motivasi, dukungan dan memberikan pertolongan baik secara fisik maupun psikologis sehingga dapat 
meningkatkan kualitas hidup anggota keluarga yang bermasalah. Dalam teori tersebut Friedman juga telah membagi dukungan keluarga menjadi 4 jenis yaitu dukungan informasional, dukungan penilaian /penghargaan, dukungan instrumental dan dukungan emosional.

Dukungan informasional, merupakan salah satu dukungan yang dapat diberikan oleh keluarga dimana keluarga berfungsi sebagai kolektor dan diseminator (penyebar) informasi yang dibutuhkan. Aspek-aspek dalam dukungan ini meliputi nasehat, usulan, saran, petunjuk dan pemberian informasi. Uraian di atas diperkuat oleh penelitian Ni'mah,S dan Alvita, GW (2017), dimana dukungan informasional sangat diperlukan oleh pasien GGK sehingga rutin dalam melakukan pengobatan (hemodialisa) yang akan berdampak pada peningkatan kualitas hidup sehari-hari.

Dukungan lain yang dapat diberikan yaitu dukungan penilaian/penghargaan dimana keluarga berperan untuk memecahkan masalah, pemberi umpan balik, memberi bimbingan dan memberikan pengaruh atas respon dari pemecahan masalah, pemberi support dan perhatian anggota keluarga yang sedang sakit. Uraian di atas diperkuat dengan penelitian Cipta (2016) menyatakan keluarga yang memberikan pujian dan penilaian fositif atas usaha-usaha pasien GGK yang menjalani hemodialisa untuk memanajemen kecemasan dirinya dalam proses pengobatan bisa menjadi apresiasi yang dapat meningkatkan semangat dan rasa optimis dalam mencapai kesembuhan juga meningkatkan harga diri dan peran social pasien GGK dalam keluarga.

Dukungan selanjutnya yang dapat diberikan yaitu dukungan instrumental di mana keluarga menjadi sumber penyedia kebutuhan materi (keuangan), barang kebutuhan seharihari (makan, minum dan istirahat) baik pada saat pasien GGK berada di rumah atau saat sedang di rawat di rumah sakit, sehingga dapat mengurangi stress pasien GGK yang menjalani hemodialisa. Uraian di atas sejalan dengan penelitian Simbolon (2018) keluarga pasien GGK yang menjalani hemodialisa mendapatkan dukungan instrumental dengan menyediakan peralatan dan perlengkapan pasien GGK menyediakan dan menyiapkan obat-abatan yang diperlukan pasien GGK selama di rumah, dan selalu menjadi penolong saat keluarganya membutuhkan bantuan contohnya saat melakukan transportasi dari rumah ke rumah sakit untuk melakukan hemodialisa.

Dukungan emosional juga merupakan salah satu hal penting yang harus diberikan oleh keluarga, dimana keluarga sebagai tempat yang aman dan damai untuk istirahat dan pemulihan serta membantu penguasaan terhadap emosi. Aspek-aspek dari dukungan emosional meliputi dukungan yang diwujudkan dalam bentuk afeksi, adanya kepercayaan, perhatian, mendengarkan dan didengarkan. Uraian diatas Sejalan dengan penelitian 
Sukriswati (2016), dimana pasien GGK yang menjalani hemodialisa yang mendapatkan dukungan emosional yang tinggi dari anggota keluarga memiliki persiapan kualitas hidup yang baik.

Hasil wawancara dengan perawat ruangan rawat inap Tulip 3BC RSUD Ulin Banjarmasin terkait dengan support sistem keluarga pada pasien GGK yang menjalani hemodialisa, perawat mengatakan pasien GGK yang menjalani hemodialisa pada bulan maret sampai juli tahun 2019 dari 196 orang pasien yang dirawat sekitar $6 \%$ yang mendapatkan support sistem yang kurang maksimal dan bahkan tidak ada support sistem dari keluarga, misalnya pada pasien GGK yang menjalani hemodialisa saat dirawat di rumahsakit tidak didampingi oleh keluarga satu orang pun da nada juga yang didampingi dengan keluarga tetapi pasien GGK (Gagal Ginjal Kronik) itu sendiri yang sering tidak mendengarkan masukan atau saran yang sudah diberikan oleh anggota keluarganya sehingga pasien yang menjalani hemodialisa terlihat tambah parah karena komplikasi yang muncul karena penyakit GGK (Gagal Ginjal Kronik) nya.

Wawancara mendalam juga dilakukan kembali kepada 5 keluarga pasien GGK (Gagal Ginjal Kronik) yang menjalani hemodialisa dimana sebagian besar menyatakan bahwa pada awalnya keluarga merasa ragu-ragu dan takut untuk mendukung dan memberikan motivasi kepada pasien untuk melakukan hemodialisa, karena sering mendapatkan informasi setiap orang yang hemodialisa akan cepat meninggal, sehingga keluarga pasien dan pasien sendiri pun tidak bersedia untuk dilakukan hemodialisa. Sampai pada akhirnya keluarga dan pasien GGK sendiri akan bersedia melakukan hemodialisa dikarenakan komplikasi yang timbul. Keputusan untuk melakukan Hemodialisa, 2 keluarga pasien mengatakan keputusan tetap dikembalikan dengan pasien GGK tersebut untuk memutuskan hemodialisanya, sedangkan 3 keluarga yang lain mengatakan pasien akan menerima keputusan yang keluarga ambil sendiri.

Keluarga pasien mengatakan dukungan untuk pasien GGK yang menjalani hemodialisa sangat perlu sekali untuk memberikan semangat dan motivasi pada pasien GGK untuk meningkatkan kualitas hidup pasien yang menjalani hemodialisa tersebut, tapi banyak pasien yang sering tidak mematuhi saran maupun masukan dari anggota keluarganya yang memberikan dukungan selama pengobatan atau selama perawatan di rumah sakit, sehingga komplikasi dari penyakit GGK itu bertambah berat.

Keluarga juga mengatakan hambatan yang sering didapatkan dalam merawat pasien GGK (Gagal Ginjal Kronik) adalah pasien yang tidak patuh dalam menjalani diet, pekerjaan keluarga yang sulit untuk ditinggalkan ataupun tempat tinggal yang sulit dijangkau. Berbeda dengan hal tersebut, terdapat 1 orang keluarga mengatakan selama memberi dukungan dengan 
pasien GGK tidak ada hambatan berjalan dengan mulus saja dan memang ada peningkatan yang lebih baik dengan pasien GGK yang menjalani hemodialisa .

Penting untuk mengetahui pengalaman keluarga memberikan dukungan pada pasein gagal ginjal kronis untuk menjalani hemodialisa. Maka pertanyaan penelitian ini adalah "Bagaimanakah pengalaman keluarga memberikan support sistem pada pasien gagal ginjal kronis yang menjalani hemodialisa di RSUD Ulin Banjarmasin”.

\section{METODE PENELITIAN}

Penelitian ini menggunakan pendekatan penelitian kualitatif dengan desain fenomenologi untuk menggali secara mendalam pengalaman keluarga memberikan support sistem pada pasien gagal ginjal kronis yang menjalani hemodialisa di RSUD Ulin Banjarmasin. Penentuan partisipan penelitian ini menggunakan teknik purposive sampling, yang berjumlah 6 partisipan keluarga pasien gagal ginjal kronis yang menjalani hemodialisa di RSUD Ulin Banjarmasin. Penelitian dilaksanakan pada bulan September - Januari 2020. Peneliti mengumpulkan data dengan cara wawancara mendalam (in-depth interview) dan metode dokumen. Teknik penelitian menggunakan teknik analisis Collaizi.

\section{HASIL PENELITIAN}

Penelitian dilakukan kepada 6 orang participant yang merupakan keluarga pasien gagal ginjal kronis yang sedang menjalani hemodialisa serta dirawat di RSUD Ulin Banjarmasin.

\section{a. Karakteristik Partisipant}

Data karakteristik participant dapat dilihat pada tabel dibawah ini :

Tabel 4.1 Karakteristik Partisipant

\begin{tabular}{|l|l|l|l|l|l|l|}
\hline P & Usia & Jenis & Suku & Pendidi & Hubu & Pekerjaa \\
& (thn) & Kela & & kan & ngan \\
min & & & Kelua & rga & \\
\hline P1 & 25 & perem & Jawa & Perguru & Anak & Mahasis \\
& & puan & & an tinggi & & wa \\
\hline P2 & 27 & perem & Banjar & Perguru & Anak & Satpol \\
\hline P3 & 43 & perem & Banjar & SD & Orang & Swasta \\
\hline P4 & 50 & Perem & Banjar & SD & Orang & Swasta \\
\hline P5 & 29 & Perem & Banjar & SLTA & Anak & Swasta \\
\hline & & puan & & & tua & \\
\hline
\end{tabular}

Tabel diatas menunjukkan data, semua participant adalah perempuan, dengan usia termuda 25 tahun dan usia tertua 50 tahun. Tingkat pendidikan terendah adalah SD dan tertinggi adalah Sarjana. Suku terbanyak adalah suku Banjar sebanyak 5 orang dan suku Jawa sebanyak 1 orang.

\section{b. Analisis Tematik}

Hasil penelitian ini memunculkan 9 buah tema yaitu sebagai berikut :

Tema 1 : Informasi Tentang Hemodialisa.

Tema 2 : Cara Keluarga Memberikan Dukungan. 
Tema 3 : Dukungan yang diberikan Keluarga.

Tema 4 : Tujuan Pentingnya dukungan keluarga.

Tema 5 : Sumber Informasi Dukungan yang diberikan.

Tema 6 : Harapan Keluarga setelah memberikan dukungan.

Tema 7 : Hambatan saat memberikan dukungan.

Tema 8 : Cara keluarga mengatasi hambatan saat memberikan dukungan.

Tema 9 : Keyakinan keluarga akan dukungan yang diberikan bisa meningkatkan kesehatan

\section{PEMBAHASAN}

\section{a. Tema 1 mengenai Sumber Informasi Tentang Hemodialisa}

Sumber informasi memegang peranan penting dalam memperoleh informasi yang akurat, kita juga perlu memperhatikan kesesuaian antara kebutuhan informasi dengan sumber informasi yang sesuai dengan kebutuhan.

Hasil penelitian menunjukan bahwa sumber informasi yang diperoleh partisipan bersumber dari orang-orang yang tepat, seperti tenaga medis baik itu dokter yang praktek di swasta maupun dokter yang bekerja di rumah sakit serta tenaga keperawatan yang bekerja di rumah sakit dan orang-orang yang sering terpapar informasi tentang cuci darah/ hemodialisa seperti keluarga pasien penderita GGK yang menjalani Hemodialisa.

Hal tersebut didukung oleh Wiliyanarti dan Muhith (2019) tingkat pengetahuan terkait tindakan hemodialisa tidak hanya dipengaruhi oleh usia, jenjang pendidikan dan informasi dari penderita GGK, melainkan juga didapatkan dari lingkungan. Kondisi lingkungan sekitar yang mendukung mempermudah proses penerimaan informasi sehingga memperbaiki tinggkat pengetahuan seseorang.

Pernyataan diatas juga didukung oleh Kusniawati (2018) kepatuhan seseorang untuk menjalani hemodialisa mengacu kepada situasi ketika perilaku seseorang individu sepadan dengan tindakan yang dianjurkan atau nasehat yang diusulkan oleh seorang praktisi kesehatan atau informasi yang diperolah dari suatu sumber informasi lainya.

Penelitian Agustina, K., \& Dewi, T.D (2013) juga mengungkapkan bahwa cargiver juga berusaha mencari segala informasi mengenai perawatan pasien hemodialisa agar dapat mendukung usaha caregiver merawat pasien yang sakit. Informasi-informasi tersebut didapat dari membaca buku dan bertanya kepada perawat maupun dokter, dengan informasi yang diperoleh tersebut, cargiver berusaha untuk lebih tanggap dengan segala situasi yang terjadi pada pasien GGK yang menjalani hemodialisa. 


\section{b. Tema 2 Cara Keluarga Memberikan Dukungan}

Hasil penelitian menunjukkan bahwa cara keluarga memberikan dukungan kepada penderita GGK yang menjalani hemodialisa/cuci darah yang dilakukan secara verbal maupun non verbal bisa memberikan motivasi dan dukungan yang tinggi bagi penderita GGK yang menjalani hemodialisa/cuci darah sehingga penderita selalu bersedia untuk menjalani tindakan hemodialisa/cuci darah tersebut.

Dukungan keluarga merupakan dukungan verbal dan non verbal, bisa berupa saran, bantuan langsung atau sikap yang diberikan oleh orang-orang yang mempunyai kedekatan dengan subjek didalam lingkungan sosialnya. Dukungan ini bisa juga berupa kehadiran yang memberi respon emosional dan mempengaruhi tingkah laku penerima dukungan tersebut. (Zurmeli, 2015)

\section{Penelitian Lukmanulhakim} mengatakan dukungan keluarga terhadap penderita GGK dengan Hemodialisa sangat dibutuhkan dalam proses penyembuhan dan pengobatan. Dukungan keluarga memainkan peranan penting dalam mengintensifkan perasaan sejahtera, orang yang hidup dalam lingkungan yang supportif kondisinya jauh lebih baik dari pada mereka yang tidak memilikinya, karena keluarga adalah orang yang paling dekat hubungannya dengan anggota keluarganya.

\section{c. Tema 3 Dukungan Keluarga yang Diberikan}

Individu merupakan sub sistem dari sebuah sistem keluarga dimana jika sub sistem terganggu maka keseluruhan sistem juga akan mengalami gangguan. Berdasarkan hal tersebut maka dapat ditarik kesimpulan maka besarnya dukungan keluarga yang diberikan kepada anggota keluarganya mempunyai pengaruh besar dalam proses penyembuhan atau pun pengobatan.

Besarnya dukungan yang diberikan oleh keluarga sangat berpengaruh besar dalam proses penobatan dan pemulihan . Keluarga sangat membantu dalam upaya pencarian informasi tentang hemodialisa/cuci darah, memberikan dukungan instrumental dalam bentuk tindakan pemberian bantuan transfortasi maupuan biaya sehari-hari penederita GGK, memberikan dukungan emosional dengan selalu memberikan kenyamanan, serta pemberian dukungan penilaian/penghargaan dengan cara selalu memberikan perhatian, kasih saying dan empati kepada penderita GGK yang menjalani hemodialisa.

Hal ini didukung oleh bahwa dukungan Ambarwati (2010) keluarga dapat memperkuat ikatan antar individu dalam meciptakan kekuatan keluarga, memperbesar pernghargaan terhadap diri sendiri, mempunyai potensi sebagai strategi pencegahan yang utama bagi seluruh keluarga dalam menghadapi tantangan kehidupan sehari-hari. 
Dukungan keluarga merupakan suatu bentuk hubungan interpersonal yang meliputi sikap, tindakan dan penerimaan terhadap anggota keluarga sehingga anggota keluarga merasa ada yang memperhatikannya (Friedman, 2010). Bentuk dukungan keluarga yang diberikan berupa dukungan emosional, dukungan informasi, dukungan instrumental/materi serta dukungan penghargaan.

\section{d. Tema 4 Tujuan Pentingnya Dukungan Keluarga}

Dukungan keluarga sangat penting diberikan pada pasien GGK yang menjalani Hemodialisa/cuci darah, karena besarnya dukungan keluarga berpengaruh terhadap kepatuhan pasien GGK yang menjalani hemodialisa/cuci darah untuk selalu rutin melakukan cuci darah dan juga pasien GGK yang hemodialisa/cuci darah mau mematuhi diet pada pasien GGK.

Setiadi (2008) menguraikan sebuah teori tentang perkembangan keluarga yang dikemukakan oleh Friedmen yaitu apabila salah satu anggota keluarga mengalami masalah pada kesehatanya maka anggota keluarga lainya yang berperan untuk memberikan motivasi, dukungan dan memberikan pertolongan baik secara fisik maupun psikologis sehingga dapat meningkatkan kualitas hidup anggota keluarga yang bermasalah.

Penelitian yang dilakukan oleh Shalahuddin dan Maulana (2015) menyatakan bahwa ada hubungan antara dukungan keluarga dengan kepatuhan pasien GGK yang menjalani hemodialisa/cuci darah, dimana tingginya tingkat dukungan keluarga akan berpengaruh besar terhadap kepatuhan pasien GGK untuk menjalani hemodialisa/cuci darah.

Mailani,F. dan Andriani,F R., (2017) dalam penelitiannya juga mengatakan bahwa adanya hubungan yang bermakna antara dukungan keluarga dengan kepatuhan diet, Untuk meningkat dukungan keluarga terhadap kepatuhan diet disarankan bagi tenaga kesehatan dan keluarga untuk memberikan informasi, perhatian dan dukungan kepada pasien dalam menjalani terapi diet.

\section{e. Tema 5 Sumber Informasi Dukungan yang diberikan}

Sumber informasi memegang peranan penting dalam memperoleh informasi yang akurat, kita juga perlu memperhatikan kesesuaian antara kebutuhan informasi dengan sumber informasi yang sesuai dengan kebutuhan.

Berdasarkan tema sumber informasi tentang dukungan yang diberikan partisipan memperoleh informasi dari tenaga medis, tenaga Keperawatan dan juga tenaga non medis.

Uraian di atas diperkuat oleh Ni'mah,S., dan Alvita, G W. (2017) dimana dukungan informasi dari sumber yang mempunyai pengalaman maupun pengetahuan baik dalam hal pengobatan, pengaturan diet maupun 
pemberian motivasi sangat diperlukan oleh pasien GGK sehingga rutin dalam melakukan hemodialisa/cuci darah.

Penelitian Shalahuddin dan Maulana (2015) juga menjelaskan banyak strategi untuk meningkatkan dukungan keluarga terhadap kepatuhan, salah satunya adalah dukungan informasi yang efektif antara keluarga dengan pasien ataupun dengan tim kesehatan seperti, dokter, perawat atau orang- orang yang pernah terpapar infomasi tentang dukungan keluarga seperti penberian informasi tentang penyakit, pengobatan maupun pemberian motivasi pada keluarga yang sedang sakit.

\section{f. Tema 6 Harapan Keluarga Setelah Memberikan Dukungan}

Harapan dalam kehidupan manusia merupakan cita-cita, keinginan maupun penantian supaya sesuatu itu terjadi. Dalam menantikan adanya sesuatu yang terjadi dan diharapkan, manusia melibatkan manusia lain atau kekuatan lain di luar dirinya supaya sesuatu itu terjadi,selain hasil usahanya yang telah dilakukan dan ditunggu hasilnya.

Pada tema harapan keluarga setelah memberikan dukungan ada 2 (dua) sub tema yang diharapkan, yaitu patuh terhadap proses pengobatan yang dalam hal ini adalah selalu bersedia hemodialisa/cuci darah dan patuh terhadap diet pada pasien GGK yang hemodialisa/cuci darah yang dalam hal ini pasien akan bersedia patuh dengan diet yang dianjurkan pada pasien GGK yan menjalani hemodialisa/cuci darah.

Uraian diatas sejalan dengan penelitian Kusniawati (2018) dimana hasil penelitian ini adalah terdapat hubungan yang bermakna antara kepatuhan menjalani terapi hemodialisis dan dukungan keluarga dengan kualitas hidup pasien gagal ginjal kronik. Semakin patuh dan semakin baik dukungan keluarga maka kualitas hidup pasien akan semakin meningkat, sehingga harapan yang diinginkan keluarga bisa terwujud.

Penjelasan diatas juga sejalan dengan penelitian Mailani dan Andriani (2017), dimana semakin besar dukungan social keluarga yang dirasakan pasien gagal ginjal kronis, maka semakin patuh pasien gagal ginjal kronis dalam melakukan diet dan sebaliknya semakin kecil dukungan social keluarga yang dirasakan pasien gagal ginjal kronis, maka semakin kurang patuh dalam melakukan diet. Patuhnya pasien GGK yang menjalani hemodialisa/cuci darah dengan bersedianya patuh terhadap diet yang dianjurkan merupakan harapan keluarga setelah memberikan dukungan.

\section{g. Tema 7 Hambatan Saat Memberikan Dukungan}

Hambatan merupakan rintangan yang ada dan terjadi dari dalam dirinya sendiri, bersifat alami. Tenaga merupakan daya yang bisa menggerakkan sesuatu atau kegiatan bekerja atau berusaha dari seseorang, dimana hal ini keluarga mempunyai hambatan tenaganya 
untuk memberikan dukungan kepada anggota keluarganya yang mana didapatkan kategori hambatan tenaga tersebut berasal dari diri keluarga itu sendiri.

Penelitian Simbolon (2018) menjelaskan data dukungan keluarga pasien hemodialisa didapatkan bahwa dukungan instrumental dalam hal ini tenaga ataupun biaya yang diberikan oleh keluarga terhadap pasien hemodialisa dikategorikan cukup (60,5\%). Keluarga merupakan sumber pertolongan yang praktis dan konkrit, diantaranya dalam hal pengawasan, keteraturan pengobatan dan kebutuhan kesehatan penderita.

Dukungan instrumental masuk dalam bentuk fungsi perawatan kesehatan dan ekonomi bagi keluarga, dimana dukungan instrumental diberikan dengan menyediakan peralatan lengkap dan memadai bagi penderita, menyediakan obato batan yang dibutuhkan, dan biaya hidup sehari -hari.

\section{h. Tema 8 Cara Keluarga Mengatasi Hambatan saat Memberikan Dukungan}

Pada tema cara keluarga mengatasi hambatan saat memberikan dukungan ada 2 (dua) subtema, yaitu tenaga dan biaya. Cara keluarga mengatasi hambatan merupakan usaha yang dilakukan keluarga untuk mengatsi hambatan yang ada saat keluarga memberikan dukungan pada keluarganya yang sakit.
Cara keluarga mengatasi hambatan dalam hal tenaga didapatkan kategori dengan cara berbagi tugas dengan anggota keluarga yang lain merupakan sesuatu yang dibagi secara bersama untuk memecahkan suatu masalah, baik itu berbagi suatu barang, cerita, kisah maupun uang untuk memecahkan masalah yang terjadi saat memberikan dukungan dengan anggota keluarga yang sedang sakit.

Sedangkan cara keluarga mengatasi hambatan dalam hal biaya didapatkan kategori dibantu keluarga, dimana saat hambatan terjadi yang berasal dari biaya diatasi dengan dibantu sama anggota keluarga yang lain atau dibantu sama orang lain bisa dari tetangga, teman atau rekan kerja.

Hambatan dalam masalah tenaga maupun biaya berkaitan dengan dukungan instrumental dimana dimana materi (biaya) maupun tenaga merupakan bentuk dukungan instrumental, seperti penyediaan biaya pengobatan dan penyediaan fasilitas yang dibutuhkan oleh anggota keluarga yang membutuhkan.

\section{i. Tema 9 Keyakinan Dari Dukungan yang Diberikan}

Keyakinan merupakan sikap yang ditunjukan oleh seseorang saat ia merasa cukup tahu dan menyimpulkan bahwa apa yang dilakukannya adalah benar.

Keyakinan partisipan terhadap dukungan yang diberikan bisa meningkatkan kesehatan pasien GGK yang menjalani hemodialisa/cuci 
darah cukup tinggi, dimana 4 (empat) orang partisipan mengatakan $75 \%$ sampai $85 \%$ mengatakan bisa sehat dan 2 (dua) orang partisipan mengatakan yakin kalau keluarganya bisa sembuh $100 \%$.

Uraian diatas sejalan dengan penelitian Simbolon (2018) didapatkan hasil analisa data kualitas hidup pasien hemodialisa di RSUD Dr. Pirngadi Medan terhadap 43 orang responden, didapatkan bahwa komponen kesehatan fisik pasien hemodialisa dalam penelitian ini dikategorikan baik $(53,5 \%)$. Kesehatan fisik dalam penelitian ini adalah upaya pasien untuk menajaga penampilan fisik, personal hygiene, nutrisi dan olah raga.

Uraian diatas juga jejalan dengan penelitian Sagiyo (2019), semakin baik dukungan keluarga yang diberikan keluarga kepada pasien maka semakin tinggi pula kualitas hidup pasien yang menjalani terapi hemodialisis, Kualitas hidup dapat berbentuk domain fisik, psikologis, hubungan sosial dan lingkungan.

\section{SIMPULAN}

Penelitian ini menghasilkan 9 buah tema yaitu: 1)Informasi Tentang Hemodialisa, 2)Cara Keluarga Memberikan Dukungan, 3)Dukungan yang diberikan Keluarga, 4)Tujuan Pentingnya dukungan keluarga, 5)Sumber Informasi Dukungan yang diberikan, 6)Harapan Keluarga setelah memberikan dukungan, 7)Hambatan saat memberikan dukungan, 8)Cara keluarga mengatasi hambatan saat memberikan dukungan, 9)Keyakinan keluarga akan dukungan yang diberikan bisa meningkatkan kesehatan.

Tema yang dihasilkan tersebut sudah menjawab tujuan dari penelitian yaitu bagaimana pengalaman keluarga memberikan dukungan pada pasien ngagal ginjal kronis yang menjalani hemodialisa di RSUD Ulin Banjarmasin. Edukasi keluarga dalam memberikan dukungannya jelas menjadi sebuah factor penting yang harus diberikan oleh pihak Rumaha sakit, sehingga tenaga kesehatan khususnya perawat diharapkan lebih memperdalam penguasaan tentang edukasi khususnya edukasi pemberian dukungan atau motivasi pada keluarga atau pasien GGK yang menjalani hemodialisa/cuci darah. penelitian ini dapat dikembangkan sebagai bahan penelitian lanjutan dalam menggali permasalahan yang menjadi penghambat keluarga memberikan dukungan pada pasien GGK (Gagal Ginjal Kronik yang menjalani hemodialisa/ cuci darah.

\section{DAFTAR RUJUKAN}

Agustina, K., \& Dewi, T.D. (2013). Strategi Coping pada Family Caregiver Pasien Gagal Ginjal Kronis yang Menjalani Hemodilisa. Jurnal Klinis dan Kesehatan Mental.

Ambarwati, E. R. (2010). Asuhan Kebidanan Nifas. . Nuha Medika : Yogyakarta.

Cipta, D. I. (2016). Hubungan Dukungan Keluraga dengan Kecemsan pada Pasien Gagal Ginjal Kronik di Unit 
Hemodialisa RS PKU Mahammadiyah Unit II Gamping Sleam Yogyakarta.

Friedman, M. M. (2010). Keperawatan Keluarga : Teori dan Praktik, edisi 3. Jakarta: EGC.

IRR, (. R. (2018). 11th Report Of Indonesian Renal Registry 2018.

Kusniawati. (2018). HUBUNGAN KEPATUHAN MENJALANI HEMODIALISIS DAN DUKUNGAN KELUARGA DENGAN KUALITAS HIDUP PASIEN GAGAL GINJAL KRONIK DI RUANG HEMODIALISA RUMAH SAKIT UMUM KABUPATEN TANGERANG. Jurnal Medikes (Media Informasi Kesehatan) Volume 5 Nomor 2 .

Lukmanulhakim, \&. L. (2017). Hubungan antara Dukungan Keluarga dengan Kejadian Depresi pada Penderita Penyakit Ginjal Kronik yang Menjalani Terapi Hemodialisa di RSUD dr. Dradjat Prawiranegara Serang. . Jurnal Ilmiah Keperawatan Indonesia.

Mailani,F., Andriani,F R., . (2017). Hubungan Dukungan Keluarga Dengan Kepatuhan Diet Pada Pasien Gagal Ginjal Kronik yang Menjalani Hemodialisis. . STIKes YPAK Padang.

Ni'mah,S., Alvita, G W., . (2017). Study Fenomenologi : Dukungan Keluarga Terhadap Kualitas Hidup Pasien Gagal Ginjal Kronik pada Usia Dewasa yang Menjalani Hemodialisa di Wilayah Kerja Puskesmas Mejobo Kudus. . Sekolah Tinggi Ilmu Kesehatan Cendikia Utama Kudus.

Sagiyo, S. (2019). HUBUNGAN DUKUNGAN KELUARGA DENGAN KUALITAS HIDUP PASIEN GAGAL GINJAL TERMINAL YANG MENJALANI TERAPI HEMODIALISIS DI RS PKU
MUHAMMADIYAH

YOGYAKARTA. UNISA Yogyakarta.

Setiadi. (2008). Konsep dan Proses Keperawatan Keluarga. Edisi Pertama. Yogyakarta: Graha Ilmu.

Setiadi, S. (2008). Konsep dan Proses Keperawatan Keluarga. Yogyakarta: Graha Ilmu.

Shalahuddin, I. M. (2015). Hubungan Dukungan Keluarga dengan Kepatuhan Pasien Gagal Ginjal Kronik dalam Menjalani Hemodialisa di Ruang Hemodialisa RSUD DR. Selamat garut. . Fakultas Keperawatan Unpad Kampus Garut.

Simbolon, N. F. (2018). Dukungan Keluarga dan Kualitas Hidup Pasien Hemodialisa di RSUD Dr. Pirngadi Medan.

Simbolon, N. F. (2018). Dukungan Keluarga dan Kualitas Hidup Pasien Hemodialisa di RSUD Dr. Pirngadi Medan.

Sukriswati, I. (2016). Hubungan dukungan keluarga dengan kualitas hidup pasien GGK yang menjalani hemodialisa di RSUD Moewardi Surakarta. Universitas Muhammadiyah Surakarta.

Wiliyanarti, Pipit Festi.,Muhith,Abd . (2019). Life Experience of Chronic Kidney Diseases Undergoing Hemodialysis Therapy. NurseLine Journal (NLJ).

Winata, Leo Chandra Wisnu Pandu;Putranto, Wachid; Fanani, Mohammad . (2017). Association between Hemodialysis Adequacy, Family Support, and Quality of Life in Chronic Renal Failure Patients . Indonesian Journal of Medicine.

Zurmeli, d. (2015). Hubungan Dukungan Keluarga dengan Kualitas Hidup Pasien Gagal Ginjal Kronik yang Menjalani Terapi Hemodialisis di RSUD Arifin Achmad Pekanbaru. 